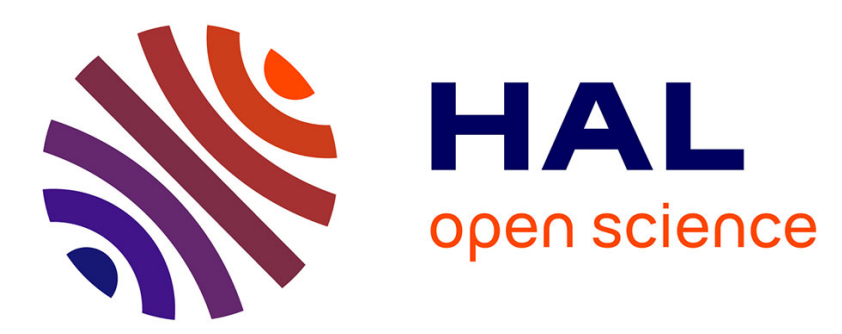

\title{
Effect of nor-trimebutine on neuronal activation induced by a noxious stimulus or an acute colonic inflammation in the rat.
}

\author{
Valérie Sinniger, Patrick Mouchet, Bruno Bonaz
}

\section{- To cite this version:}

Valérie Sinniger, Patrick Mouchet, Bruno Bonaz. Effect of nor-trimebutine on neuronal activation induced by a noxious stimulus or an acute colonic inflammation in the rat.. Life Sciences, 2005, 77 (23), pp.2927-41. 10.1016/j.lfs.2005.05.030 . inserm-00388054

\section{HAL Id: inserm-00388054 https://www.hal.inserm.fr/inserm-00388054}

Submitted on 31 Jul 2009

HAL is a multi-disciplinary open access archive for the deposit and dissemination of scientific research documents, whether they are published or not. The documents may come from teaching and research institutions in France or abroad, or from public or private research centers.
L'archive ouverte pluridisciplinaire HAL, est destinée au dépôt et à la diffusion de documents scientifiques de niveau recherche, publiés ou non, émanant des établissements d'enseignement et de recherche français ou étrangers, des laboratoires publics ou privés. 
EFFECT OF NOR-TRIMEBUTINE ON NEURONAL ACTIVATION INDUCED BY A NOXIOUS STIMULUS OR AN ACUTE COLONIC INFLAMMATION IN THE RAT

Valérie Sinniger(1,2), Patrick Mouchet (1), and Bruno Bonaz $(1,2)$

(1) Groupe d'Etudes du Stress et des Interactions Neuro-Digestives (GESIND ; EA3744), and (2) Département d'Hépato-Gastroentérologie, CHU de Grenoble, BP 217, 38043 Grenoble cedex 09, France

Author to whom proofs and correspondence should be sent Pr B.Bonaz, Département d'Hépato-Gastroentérologie, CHU de Grenoble, BP 217, 38043 Grenoble cedex 09, France. Phone: (33 4) 76765597 Fax: (33 4) 76765297 e-mail: Bruno.Bonaz@ujfgrenoble.fr

\section{Section heading}

Neuroscience 


\begin{abstract}
Nor-trimebutine is the main metabolite of trimebutine which is used in the treatment of patients with irritable bowel syndrome. Nor-trimebutine has a blocking activity on sodium channel and a potent local anaesthetic effect. These properties were used to investigate the effect of nortrimebutine on spinal neuronal activation induced by models of noxious somato-visceral stimulus and acute colonic inflammation. Nor-trimebutine was administered subcutaneously in rats $30 \mathrm{~min}$ before intraperitoneal administration of acetic acid or intracolonic infusion of trinitrobenzenesulfonic acid. Abdominal contractions were counted for $1 \mathrm{~h}$ as a marker of abdominal pain. c-fos expression was used as a marker of neuronal activation and performed by immunohistochemistry $1 \mathrm{~h}$ after intraperitoneal acetic acid and $2 \mathrm{~h}$ after colonic inflammation. Nortrimebutine decreased Fos expression in the thoraco-lumbar (peritoneal irritation) and lumbo-sacral (colonic inflammation) spinal cord in laminae I, IIo V, VII and X. This effect was also observed in the sacral parasympathetic nucleus after colonic inflammation. Nor-trimebutine induced a significant decrease of abdominal contractions following intraperitoneal acetic acid. These data may explain the effectiveness of trimebutine in the therapy of abdominal pain in the irritable bowel syndrome.
\end{abstract}

\title{
Keywords
}

c-fos ; colitis ; somato-visceral pain ; trimebutine ; visceral afferents. 


\section{INTRODUCTION}

Trimebutine (TMB) has been efficiently used in many countries since 1969 for the treatment of functional bowel disorders (Moshal et al., 1979; Lüttecke, 1980; Toussaint et al., 1981; Ghidini et al., 1986; Poynard et al., 2001), including irritable bowel syndrome (IBS), which is characterized by a visceral hypersensitivity (Ritchie, 1973). Besides its regulatory effects on colonic motility through its weak opioid properties, TMB is also able to influence the activity of visceral afferents (Julia et al., 1996; Roman et al., 1999) thus explaining its beneficial effects on abdominal pain in IBS patients. This effect is most likely due to its blocking activity on sodium channels (Roman et al., 1999). After oral administration in humans, TMB is metabolized in the liver to give nortrimebutine (nor-TMB), the main metabolite of $\mathrm{TMB}$, which reaches plasma levels higher than those of TMB itself (Roman et al., 1999). Nor-TMB has similar or more potent effects than TMB itself on sodium channel blockade and glutamate release inhibition (Lüttecke, 1980; Toussaint et al., 1981; Ghidini et al., 1986; Roman et al., 1999). This effect is of potential therapeutic interest not only in pain but also in inflammatory processing. Indeed, inflammation is well known to sensitise afferent fibers to pain (Bueno and Fioramonti, 1999) and IBS symptoms have been observed after infectious diarrhoea (Gwee et al., 1996) and in patients with inflammatory bowel diseases (IBD) in remission (Isgard et al., 1983). Intraperitoneal (ip) injection of acetic acid (AA) is a well known noxious chemical somato-visceral stimulus in rats (Koster et al., 1959; Menetrey et al., 1989; Hammond et al., 1992; Lanteri-Minet et al., 1993) as evidenced by the presence of abdominal contractions (Koster et al., 1959; Pairet et al., 1989; Rivière et al., 1993, 1994). Intracolonic (ic) instillation of trinitrobenzenesulfonic acid (TNBS) is a simple and reproducible model of colonic inflammation in rat (Morris et al., 1989). Fos, the protein product of the immediate early gene $c-f o s$ is a sensitive marker of neuronal activation classically used to localize 
spinal cord neurons responsive to acute stimuli of somatic or visceral origin (Menetrey et al., 1989; Hunt et al., 1987; Herdegen et al., 1991; Traub et al., 1992, 1993). Using the model of somatovisceral pain, we have previously shown that, fedotozine, a kappa-opioid receptor agonist known to improve abdominal symptoms in IBS patients (Dapoigny et al., 1995; Delvaux et al., 1999), has an antinociceptive effect and prevents AA-induced Fos expression in the thoraco-lumbar spinal cord in rats through a peripheral action on visceral afferents (Bonaz et al., 2000).

In this study, we investigated in rats, the effects of nor-TMB on the induction of Fos expression in the spinal cord, i.e. the site of primary somato-visceral afferents, in the model of AAinduced somato-visceral pain and TNBS-induced acute colonic inflammation. 


\section{METHODS}

\section{Animals}

Adult male Sprague-Dawley rats (250-300g; Charles River Laboratories, L'Abresle, France) were separately housed in a temperature-controlled environment $\left(22 \pm 1^{\circ} \mathrm{C}\right)$ with food and water available ad libitum and a 12 hours on / 12 hours dark light cycle (lights at 8 a.m.). Animals were acclimatized to their environment for at least 7 days prior to the experiments. Because diurnal variations of Fos expression have been reported in some brain areas (Kononen et al., 1990), experiments were performed between 10:00 a.m. and 1:00 p.m. in animals deprived of food but not water for at least 18 hours. Protocols were conformed to the author's institution's animal care and use committee.

\section{Noxious somato-visceral stimulus}

Somato-visceral pain was induced in conscious rats $(n=5)$ with ip injection of $0.6 \%$ AA (10 $\mathrm{ml} / \mathrm{kg}$ ) in the right lower quadrant of the abdomen as previously described (Bonaz et al., 2000). Control animals $(\mathrm{n}=5)$ received the vehicle alone (saline ip: $10 \mathrm{ml} / \mathrm{kg}$ ). Somato-visceral pain was assessed by counting abdominal contractions (Koster et al., 1959; Giamberardino et al., 1995; Bonaz et al., 2000) for 60 minutes, by periods of $10 \mathrm{~min}$, following the ip injection of AA, classically described as the writhing test (Koster et al., 1959). Abdominal contractions consisted of the contraction of the flank muscles associated with inward movements of the hindlimb or with whole body stretching (Giamberardino et al., 1995).

\section{Acute colonic inflammation}

Rats were anesthetised with a mixture of sodium pentobarbital and chloralhydrate ( $4 \mathrm{ml} / \mathrm{kg} \mathrm{ip})$ (Bonaz et al., 2000). A silicone catheter (ID, $1.2 \mathrm{~mm}$; OD, $1.7 \mathrm{~mm}$ ) was chronically implanted into 
the distal colon $7-8 \mathrm{~cm}$ from the anus. The catheter was fixed at the colonic wall by a purse-string suture, tunnelled subcutaneously and externalised at the back of the neck where it was secured at the animal's skin. After surgery, animals were housed separately for at least 7 days prior to testing. Experiments were performed in conscious freely moving rats equipped with this chronic catheter to avoid the possible confounding effects of stress-induced manipulation of the animals on c-fos expression (Kovacs, 1998). Inflammation of the colon was induced through the catheter with a single ic administration of $0.25 \mathrm{ml}$ of $50 \%$ ethanol containing $30 \mathrm{mg}$ of TNBS (Fluka, St Quentin Fallavier, France) as previously described (Morris et al., 1989). The instillation procedure required $\sim 5 \mathrm{~s}$ to complete. Catheter was then slowly flushed with $0.2 \mathrm{ml}$ air to expel any inducing agent remaining in the catheter. Control animals received $0.25 \mathrm{ml}$ of $0.9 \%$ saline according to the same procedure. Assessment of colonic damage was performed after sacrifice of the animals for Fosimmunohistochemistry processing. After completion of the perfusion, the distal colon was isolated, opened by a longitudinal incision, rinsed with saline and then pinned out on a wax block and examined macroscopically.

\section{Drugs}

In the model of somato-visceral pain, nor-TMB (10 or $30 \mathrm{mg} / \mathrm{kg}$ subcutaneously (sc) dissolved in $250 \mu \mathrm{l}$ saline; $\mathrm{n}=5$ in each group) or the vehicle $(250 \mu \mathrm{l}$ saline subcutaneously; $\mathrm{n}=5)$ was administered $30 \mathrm{~min}$ before ip injection of AA. The effect of nor-TMB (10 or $30 \mathrm{mg} / \mathrm{kg}$ in $250 \mu \mathrm{l}$ saline subcutaneously; $\mathrm{n}=5$ ) alone on Fos expression was also investigated 90 min after injection.

In the model of acute colonic inflammation, nor-TMB (30 mg/kg dissolved in $250 \mu \mathrm{l}$ saline; $\mathrm{n}=5)$ or the vehicle ( $250 \mu \mathrm{l}$ saline; $\mathrm{n}=5)$ was administered ic, 30 minutes before induction of colitis. The dose of $30 \mathrm{mg} / \mathrm{kg}$ was chosen based on the somato-visceral pain procedure showing that this dose 
decreased abdominal contractions counted during $60 \mathrm{~min}$. The effect of ic injection of nor-TMB alone $(\mathrm{n}=3)$ on Fos expression was also investigated $2 \mathrm{~h} 30$ after administration of the compound.

\section{Fos immunohistochemistry}

Fos immunohistochemistry was performed as previously described (Bonaz et al., 1994, 2000). Sixty min after ip AA or 2 hours after intracolonic TNBS, rats were sacrificed. The 1h-interval after ip AA was selected based on previous studies (Bonaz et al., 1994; 2000). The 2h-interval after ic instillation of TNBS was selected based on a time course effect on Fos expression in the spinal cord in preliminary studies (personnal unpublished data). Animals were deeply anesthetised with an ip injection of a mixture of sodium pentobarbital and chloralhydrate $(4 \mathrm{ml} / \mathrm{kg}$ ip) and then transcardially perfused with $100 \mathrm{ml}$ of isotonic saline followed by $600 \mathrm{ml}$ of $4 \%$ paraformaldehyde in $0.1 \mathrm{M}$ phosphate buffer (PB; $\mathrm{pH} 7.4$ ). Spinal cords were rapidly removed, postfixed for 3 hours at $+4^{\circ} \mathrm{C}$ in the same fixative and subsequently cryoprotected overnight in $20 \%$ sucrose in $0.1 \mathrm{M}$ PB. Coronal frozen sections $(30 \mu \mathrm{m})$ of the spinal cord (thoracic, lumbar and sacral levels) were cut on a cryostat (Microm, Lyon, France) and processed for Fos-IR. Free-floating sections were incubated for $16-18$ hours at $+4^{\circ} \mathrm{C}$ with the primary antibody (Fos AB-5 rabbit polyclonal antibody, Oncogen Science; dilution 1:1000 in PB saline, 0.02M, containing 0.5\% Triton X-100 and 10\% normal goat serum) and then with a biotinylated secondary antibody (goat anti-rabbit, Sigma, St Louis, MO; dilution 1:100) for 2 hours at room temperature. Sections were finally processed for avidin-biotinperoxidase using diaminobenzidine as the chromogen (Sigma), then mounted on gelatin-coated slides, dehydrated, cleared in xylene, and coverslipped.

Fos quantification. The presence of Fos immunoreactivity (Fos-IR) was detected by brightfield microscopy as a brown-black reaction product in cell nuclei. No Fos-IR was observed in sections when the primary antibody was omitted. Fos count was performed as previously described (Bonaz 
et al., 1994, 2000). In the model of somato-visceral pain, Fos positive cells were counted at the thoraco-lumbar level (T10-L2) of the spinal cord as previously described (Bonaz et al., 2000) on 20 consecutive sections, in specific laminar regions of the spinal gray matter i.e. laminae I-outer II (IIo), V, VII and X, using the cytoarchitectonic organization of the spinal cord described by Molander (Molander et al., 1984, 1989). In the model of acute colonic inflammation, Fos-IR was counted on 20 consecutive sections at the lumbo-sacral level (L6-S2) in the same laminae as well as in the sacral parasympathetic nucleus (SPN) at $\mathrm{S} 1$ level. To estimate the total number of neurons, counts were corrected for double-counting errors by the formula of Abercrombie (1946): corrected count $=$ total count $\mathrm{x}$ (section thickness/average diameter of neurons + section thickness). In both models, Fos count was expressed as either total (laminae I-IIo+V+VII+X) or individual (lamina IIIo, V, VII, X). Cell counting was performed in blind conditions to avoid bias.

\section{Statistical analysis}

Data are expressed as means \pm standard error of the mean (S.E.M). Difference between means of Fos-positive cells within different spinal segments were determined by a variance analysis (ANOVA). Post hoc comparison between groups was evaluated by the Tukey test. Data were considered statistically significantly when $\mathrm{P}<0.05$. 


\section{RESULTS}

\section{Effect of nor-TMB on acetic acid-induced abdominal contractions}

In control animals, almost no abdominal contraction was observed while a dramatic increase of abdominal contractions was counted during visual observation of the animals for 60 minutes following AA ip (Fig 1A). Nor-TMB, administered at a dose of 10 or $30 \mathrm{mg} / \mathrm{kg} \mathrm{sc}$, did not significantly modify the number of AA-induced abdominal contractions when considering the overall period of 60 min while a non significant decrease of abdominal contractions was observed with the dose of $30 \mathrm{mg} / \mathrm{kg}$ (Fig 1A). In contrast, a significant decrease of abdominal contractions was observed for both doses when considering the last 2 periods of 10 minutes (from 40 to $60 \mathrm{~min}$ ) following AA ip (Fig 1B).

\section{Effect of nor-TMB pretreatment on acetic acid-induced Fos-IR}

In control animals receiving $250 \mu \mathrm{l}$ saline sc $30 \mathrm{~min}$ before $10 \mathrm{ml} / \mathrm{kg}$ saline ip, almost no Fos-IR was observed in the spinal cord, as previously described (Bonaz et al., 2000) (data not shown). Animals pre-treated sc with saline and then with ip AA presented the same pattern of Fos-IR than previously described (Bonaz et al., 2000). Fos labeling was essentially distributed at the thoracolumbar level (T10-L2) mainly in the superficial dorsal horn (lamina I-IIo) but also in laminae V, VII and in the region surrounding the central canal i.e. lamina $\mathrm{X}$ (Fig2A, Figs 3A,B). These neurons were predominantly concentrated on the side ipsilateral to the injection site although they were also present in reduced numbers on the controlateral side. Few Fos-IR neurons were observed in laminae III and IV. A few labelled cells were observed in the region of the intermediolateral cell column. The number of Fos positive neurons in the different laminae is detailed in Figs 3 A,B. Almost no Fos-IR was observed at the cervical, upper thoracic and sacral levels (data not shown). Nor-TMB (10 or $30 \mathrm{mg} / \mathrm{kg} \mathrm{sc})$ administered alone did not induced any significant Fos-IR in the 
spinal cord (data not shown). Nor-TMB at a dose of 10 or $30 \mathrm{mg} / \mathrm{kg} \mathrm{sc}$ significantly decreased total Fos count in AA-treated rats (Fig2B, Figs 3A,B). The significant decrease of Fos count for the dose of $10 \mathrm{mg} / \mathrm{kg}$ sc was 52\%, 74.5\%, 79\%, 78\% in laminae I-IIo, V, VII, and X respectively (Fig 3B). The higher dose (30 mg/kg sc) of nor-TMB produced a similar effect: 59\%, 79\%, 79\% and 83\% in laminae I-IIo, V, VII, and X respectively (Fig 3B).

\section{Effect of nor-TMB pre-treatment on acute colonic inflammation-induced Fos-IR}

Ic administration of $0.9 \%$ saline alone did not produce any behavioural modification of the animals as well as any macroscopically detectable damage of the recto-colon. All animals receiving TNBS/ethanol showed reduced fluid and food intake, diarrhoea, piloerection, lack of preening, and a reduced level of activity during the $2 \mathrm{~h}$ following induction of colitis. Ic administration of TNBS did not induced any abdominal contraction. Extensive macroscopic damage of the colon was observed in all animals at the site of TNBS instillation. The mucosa appeared ulcerated and haemorrhagic. The site of inflammation generally involved the rectum until the splenic flexure. Damage was rarely observed before the splenic flexure. No macroscopic abnormality of the liver, spleen, kidney, ileum, jejunum or duodenum was observed.

In control animals receiving $250 \mu \mathrm{l}$ saline ic $30 \mathrm{~min}$ before $250 \mu \mathrm{l}$ saline ic, few Fos-IR was observed in the spinal cord (Fig 4A). In animals receiving ic injection of saline and TNBS 30 min later, a strong Fos-IR was observed in the spinal cord, predominantly in L6-S2 segments. Fos-IR was distributed in laminae I-IIo, V, VII and X and in the SPN (Fig2C, Figs 4 A,B). A very few Fos IR was observed at the thoracolumbar level (T10-L2) (data not shown). Ic injection of nor-TMB alone did not induced any Fos-IR in the spinal cord (data not shown). In animals pretreated with nor-TMB (30 mg/kg ic) $30 \mathrm{~min}$ before TNBS injection, a significant decrease of total Fos count was observed in the spinal cord at L6-S2 segments and in the SPN (Fig2D, Fig 4A). This decrease was 
$62 \%(\mathrm{P}<0.05), 48 \%(\mathrm{NS}), 66 \%(\mathrm{NS}), 78 \%(\mathrm{P}<0.05)$ and $75 \%(\mathrm{P}<0.05)$ in laminae I-IIo, $\mathrm{V}, \mathrm{VII}, \mathrm{X}$ and in the SPN respectively (Fig 4B). 


\section{DISCUSSION}

The present study shows that nor-TMB, the main metabolite of TMB, used in the treatment of IBS, is able to decrease neuronal activation induced in the spinal cord by a noxious somato-visceral stimulus or an acute colonic inflammation.

Nor-TMB is the major circulating compound after oral administration of TMB in humans and has similar or more potent effects than TMB itself (Roman et al., 1999). TMB, nor-TMB and their corresponding stereoisomers inhibit veratridine-induced glutamate release in vitro (Roman et al., 1999). Glutamate is an excitatory amino acid known to mediate spinal transmission of peripheral nociceptive input (Scatton, 1993; Urban et al., 1994), by activating voltage-dependent sodium channels (Wermelskirchen et al., 1992). The effect of TMB and nor-TMB is not due to their opioid properties but to their blocking activities on voltage-dependant sodium channels (Roman et al., 1999) which are expressed in primary sensory neurons and are important targets in the study of the molecular pathophysiology of pain (Waxman et al., 1999). The sodium channel blocking activity is confirmed by the potent local anaesthetic effect of TMB which is 17-fold more active than lidocaine (Roman et al., 1999), an effective drug in the treatment of human and experimental colitis (Bjorck et al., 1989, 1992). TMB and/or nor-TMB may influence activity of visceral afferents in rats as represented by an inhibition of the rectocolonic reflex (Julia et al., 1996) and rectal hyperalgesia evoked by TNBS-induced colitis and stress in rats (Lacheze et al., 1998), as well as by a blockade of sodium currents in sensory neurons from rat dorsal root (Roman et al., 1999). NorTMB has also an antinociceptive effect in a model of neuropathic pain in rats (Kayser et al., 2000). The properties of TMB and nor-TMB may explain the effectiveness of TMB in the therapy of abdominal pain in IBS patients (Lüttecke, 1980; Toussaint et al., 1981; Ghidini et al., 1986; Poynard et al., 2001). 
In the model of somato-visceral stimulus, neuronal activation induced by AA ip was observed in the same locations and laminae of the spinal cord as we (Bonaz et al., 2000) and others (Menetrey et al., 1989; Hammond et al., 1992; Lanteri-Minet et al., 1993) have previously described. Indeed, Fos-IR was observed in laminae I, IIo, V, and X, reported to receive unmyelinated (C) as well as fine myelinated $(\mathrm{a} \delta)$ somato-visceral afferents (Neuhuber, 1982, 1986; Sugiura et al., 1989) while Fos-IR cells observed in lamina VII most likely corresponds to polysynaptically activated neurons (Hammond et al., 1992; Bonaz et al., 2000). Lamina VII has been shown to receive projections from muscle nerves in the rat (Molander and Grant, 1987). Moreover, some cells of lamina VII are part of the spinoreticular tract, one of the ascending nociceptive pathways. Laminae I, IIo, V, VII and $\mathrm{X}$ are important regions for rostral transmission of nociceptive information to a number of sites which are involved in homeostasis and visceral integration (Menetrey and Basbaum, 1987; Menetrey and Pommery, 1991; Giesler et al., 1994; Al-Chaer et al., 1996, 1997; Bester et al., 1997; Bourgeais et al., 2001) and underly the production or modification of neuroendocrine, autonomic, affective and emotional responses to painful stimuli (Berthier et al., 1988; Yasui et al., 1991; Katter et al., 1996; Zhang et al., 1999). The few Fos-IR observed in laminae III-IV is most likely induced by the motor activity of abdominal contractions due to peritoneal irritation. Lamina III contains numerous fine myelinated fibers, but many cells respond only to weak mechanical stimuli (Cervero, 1988). Lamina IV cells respond to proprioceptive and cutaneous stimuli (Matsushita et al., 1979) and also only to light mechanical stimuli (Cervero, 1988). The effect of nor-TMB in decreasing neuronal activation was not dose-dependent since the decrease of Fos-IR in the spinal cord was in the same order of magnitude either with 10 or with $30 \mathrm{mg} / \mathrm{kg} \mathrm{sc}$. We did not test a smaller dose than $10 \mathrm{mg} / \mathrm{kg}$ since experimental data have shown that TMB is active on abdominal pain from 10 $\mathrm{mg} / \mathrm{kg}$ (Julia et al., 1996). The antinociceptive effect of nor-TMB was confirmed by a significant decrease of abdominal contractions as observed from 40 to 60 min following AA ip. These data are 
close to the ones we have observed with fedotozine (Bonaz et al., 2000), a kappa opioid agonist able to improve abdominal symptoms in IBS patients (Dapoigny et al., 1995; Delvaux et al., 1999). In the present study, the selection of a 1h-interval after AA ip was based on previous studies (Bonaz et al., 1994, 2000); this is also the optimal time interval to reveal Fos expression after exposure to various types of stimuli (Morgan and Curran, 1990).

In the model of acute colonic inflammation, the localization of Fos-IR in the lumbosacral (L6S2) and at a lesser extent in the thoraco-lumbar segments of the spinal cord is in agreement with the topographical distribution of afferent projections from the colon and rectum (Ness and Gebhart, 1990). At L6-S2 segment, Fos was located primarily in the superficial layers of the dorsal horn (i.e. laminae I-IIo), in lamina VII, in area X surrounding the central canal, and in the SPN. This distribution matches the rostro-caudal and topographical central projections of pelvic afferents established to terminate in laminae I, IIo, V, VI and VII, and the dorsal part of area X (Morgan et al., 1981; Nadelhaft and Booth, 1984; De Groat, 1986; Pascual et al., 1989). This distribution is also in agreement with the one observed after colorectal (Traub et al., 1992, 1993) or proximal colon distension (Martinez et al., 1998), as well as after electrical stimulation of the pelvic nerve (Birder et al., 1991) or after chemical irritation of the lower urinary tract (Birder et al., 1999). Few Fos-IR was also observed in the thoraco-lumbar spinal cord as observed by Traub et al. (1992, 1993). Nor-TMB decreased Fos-IR in laminae I-IIo, V, VII, and X, as well as in the SPN, with a significant effect in lamina I-IIo, X and the SPN while the decrease was nearly significant in laminae V and VII. The parasympathetic preganglionar pathway to the pelvic organ arises in the L6-S1 spinal segments in the rat (Nadelhaft and Booth, 1984). The SPN has an important role in the regulation of various pelvic organ functions including micturition, defecation and penile erection (De Groat et al., 1996). Neurons in the SPN have extensive axon collaterals with abundant synaptic connections with neurons in area $\mathrm{X}$ surrounding the central canal, but also 
with neurons in laminae I, V, VII and IX (Morgan et al., 1991). The activation of neurons within the SPN could thus participate, at least in part, to the Fos-IR observed around the central canal (laminae X). Mawe et al (1986) have also shown connections between primary sacral afferent fibers and dendrites of labelled neurons in the SPN. These connections thus provide evidence for sensory and autonomic reflex integration and could explain the induction of Fos expression in the SPN and the preventive effect of nor-TMB on Fos-IR in the SPN. In this model, only one dose of nor-TMB (30 mg/kg) was used, based on the somato-visceral pain procedure showing that this dose decreased abdominal contractions counted during $60 \mathrm{~min}$.

In the present study, nor-TMB has been administered by two different routes (sc and ic). Consequently, the results may reflect different sites and modes of action of nor-TMB. Indeed, we may evoke: 1) A possible blocking activity effect on somato-visceral afferents through the properties of the drug (Roman et al., 1999). An influence of the compound on visceral afferents and dorsal root ganglia culture neurons has been observed in rats (Julia et al., 1996; Roman et al., 1999; Lacheze et al., 1998), 2) An anti-inflammatory action in the model of acute colonic inflammation, through the potent local anaesthetic properties of the compound on visceral afferents (Roman et al., 1999). One might argue that second or third order neurons are activated in the spinal cord, all of which receive modulatory descending influences suggesting a role in the descending control of pain. We did not perform $c$-fos expression in spinal transected animals to be sure that the distribution of Fos positive neurons was similar in spinal intact and spinal transected animals thus indicating that $c$-fos expression was mediated by monosynaptic afferent input or input from segmental interneurons and was not due to activation of supraspinal pathways. However, it has been shown that in spinally transected rats the induction of Fos-IR was significantly increased 3 days, but not 2 h, following inflammation (Ren and Ruda, 1996). In the present study, $c$-fos expression was performed $1 \mathrm{~h}$ or $2 \mathrm{~h}$ after peritoneal or colonic inflammation 
respectively. Although nor-TMB administered alone sc or ic did not induce any significant Fos-IR in the spinal cord, one can wonder that this does not rule out a central effect of the drug. However, it has been shown that the stimulating effect of TMB on intestinal motility (phase 3) is not reproduced after intracerebroventricular administration and is abolished by previous intravenous, but not intracerebroventricular, administration of naloxone (Honde et al., 1989). One can wonder that nor-TMB was given systemically (sc) and locally (ic) at times before AA or TNBS and sacrifice that do not prevent nor-TMB from accessing all of the neuraxis, including afferent and efferent fibers, spinal cord neurons and supraspinal sites (not explored in the present study). However, this time course is the one generally used in experimental studies on visceral pain with TMB and nor-TMB (Julia et al., 1996; Lacheze et al., 1998). Despite the two different routes of administration of the compound, the same laminae of the spinal cord, mostly involved in somatovisceral processing, were activated.

In the present study, we were only looking at the acute effects of a noxious or inflammatory insult. However, experimental data have also shown an effect of TMB and nor-TMB on rectal hyperalgesia induced by local inflammation and stress (Lacheze et al., 1998); these effects might explain the efficacy of TMB in the treatment of IBS. Inflammation is well known to sensitize afferent fibers to pain (Bueno and Fioramonti, 1999) and symptoms of IBS have been observed in patients with IBD in remission (Gwee et al., 1996). Consequently, TMB could also be of potential interest in treating abdominal pain either in IBD or in IBD patients with IBS symptoms. 


\section{ACKNOWLEDGEMENTS}

This work was supported by Pfizer France. We are very grateful to Mrs Catherine Pecout, from Pfizer France, for her help in the accomplishment of this work. 


\section{REFERENCES}

Abercrombie; M., 1946. Estimation of nuclear population from microtome sections. Anat Rec 94, 239-247.

Al-Chaer, E.D., Lawand, N.B., Westlund, K.N., Willis, W.D., 1996. Visceral nociceptive input into the ventral posterolateral nucleus of the thalamus: a new function for the dorsal column pathway. $\mathbf{J}$ Neurophysiol 76, 2661-2674.

Al-Chaer, E.D., Westlund, K.N., Willis, W.D., 1997. Nucleus gracilis: an integrator for visceral and somatic information. J Neurophysiol 78, 521-527.

Berthier, M., Starkstein, S., Leiguarda, R., 1988 Asymbolia for pain: a sensory-limbic disconnection syndrome. Ann Neurol 24, 41-49.

Bester, H., Matsumoto, N., Besson, J.M., Bernard, J.F., 1997. Further evidence for the involvement of the spinoparabrachial pathway in nociceptive processes: a c-Fos study in the rat. J Comp Neurol $383,439-458$.

Birder, L.A., Roppolo, J.R., Iadarola, M.S., De Groat, W.C., 1991. Electrical stimulation of visceral afferent pathways in the pelvic nerves increases c-fos in the rat lumbosacral spinal cord. Neurosci Lett 129, 193-196.

Birder, L.A., Roppolo, J.R., Erickson, V.L., De Groat, W.C., 1999. Increased c-fos expression in spinal lumbosacral projection neurons and preganglionic neurons after irritation of the lower urinary tract in the rat. Brain Res 834, 55-65.

Bjorck, S., Dahlstrom, A., Ahlman, H., 1989. Topical treatment of ulcerative proctitis with lidocaine. Scand J Gastroenterol 24, 1061-1072.

Bjorck, S., Dahlstrom, A., Johansson, L., Ahlman, H., 1992. Treatment of the mucosa with local anaesthetics in ulcerative colitis. Agent Actions Spec N ${ }^{\circ}$, C60-72 
Bonaz, B., Plourde, V., Taché, Y., 1994. Abdominal surgery induces fos immunoreactivity in the rat brain. J Comp Neurol 349, 212-222.

Bonaz, B., Riviere, J.M., Sinniger, V., Pascaud, X., Junien, J.L., Fournet, J., Feuerstein, C., 2000. Fedotozine, a kappa-opioid agonist, prevents spinal and supra-spinal Fos expression induced by a noxious visceral stimulus in the rat. Neurogastroenterol Motil 12, 135-147.

Bourgeais, L., Monconduit, L., Villanueva, L., Bernard, J.F., 2001. Parabrachial internal lateral neurons convey nociceptive messages from the deep laminas of the dorsal horn to the intralaminar thalamus. J Neurosci 21, 2159-2165.

Bueno, L., Fioramonti, J., 1999. Effects of inflammatory mediators on gut sensitivity. Can J Gastroenterol. 13 Suppl A, 42A-46A.

Cervero, F., 1988. Neurophysiology of gastrointestinal pain. Baillieres Clin Gastroenterol 2, 183199.

Dapoigny, M., Abitbol, J.L., Fraitag, B., 1995. Efficacy of peripheral kappa agonist fedotozine versus placebo in treatment of irritable bowel syndrome. A multicenter dose-response study. Dig Dis Sci 40, 2244-2248.

De Groat, W.C., 1986. Spinal cord projections and neuropeptides in visceral afferent neurones. Prog Brain Res 67, 165-187.

De Groat, W.C., Vizzard, M.A., Araki, V.I., Roppolo, J., 1996. Spinal neurons and preganglionic neurons in sacral autonomic reflex pathways. In: Holstege, G., Bandler, R., and Saper, C.B., (Ed). The emotional motor system. Progress in Brain Research. Vol. 107, Elsevier Science, B.V., pp 97111.

Delvaux, M, Louvel, D, Lagier, E, Scherrer, B., Abitbol, J.L., Frexinos, J., 1999. The kappa agonist fedotozine relieves hypersensitivity to colonic distension in patients with irritable bowel syndrome. Gastroenterology 116, 38-45. 
Ghidini, O., Saponati, G., Intrieri, L., 1986. Single drug treatment for irritable colon: rociverine versus trimebutine maleate. Curr Ther Res 39, 541-548.

Giamberardino, M.A., Valente, R., de Bigontina, P., Vecchiet, L., 1995. Artificial ureteral calculosis in rats: behavioural characterization of visceral pain episodes and their relationship with referred lumbar muscle hyperalgesia. Pain 3, 459-469.

Giesler, G.J. Jr., Katter, J.T., Dado, R.J., 1994. Direct spinal pathways to the limbic system for nociceptive information. Trends Neurosci 17, 244-250.

Gwee, K.A., Graham, J.C., McKendrick, M.W., Collins, S.M., Marshall, J.S., Walters, S.J., Read, N.W., 1996. Psychometric scores and persistence of irritable bowel after infectious diarrhoea. Lancet 347, 150-153.

Hammond, D. L., Presley, R., Gogas, K.R., Basbaum, A.I., 1992. Morphine or U-50,488 suppresses fos-protein-like immunoreactivity in the spinal cord and nucleus tractus solitarii evoked by a noxious visceral stimulus in the rat. J Comp Neurol 315, 244-253.

Herdegen, T, Tolle, TR, Bravo, R, Zieglgansberger, W, Zimmermann, M., 1991. Sequential expression of JUN B, JUN D and FOS B proteins in rat spinal neurons: cascade of transcriptional operations during nociception. Neurosci Lett 129, 221-224.

Honde, C., Le Gallou, B., Pascaud, X., Junien, J.L., 1989. Effect of trimebutine on intestinal motility in dogs. Presse Med 18, 294-297.

Hunt, S.P., Pini, A., Evan, G., 1987. Induction of c-fos-like protein in spinal cord neurons following sensory stimulation. Nature 328, 632-634.

Isgard, B., Harman, M., Kaye, M.D., Whorwell, P.J., 1983. Symptoms of irritable bowel syndrome in ulcerative colitis in remission. Gut 24, 190-192. 
Julia, V., Coelho, A.M., Rouzade, M.I., Allouche, S., Bueno, L., 1996. Influence de la trimébutine (Débridat) sur l'hypomotricité colique et les crampes abdominales liées à la distension rectale chez le rat. Med Chir Dig 25, 239-242.

Katter, J.T., Dado, R.J., Kostarczyk, E., Giesler, G.J. Jr., 1996. Spinothalamic and spinohypothalamic tract neurons in the sacral spinal cord. II. Responses to cutaneous and visceral stimuli. J Neurophysiol 75, 2606-2628.

Kayser, V., Christensen, D., Guilbaud, G., Roman, F., 2000. Antinociceptive effect of nor-TMB against a mechanical stimulus in a rat model of peripheral neuropathy. Life Sci 66, 433-439.

Kononen, J., Koistinaho, J., Alho, H., 1990. Circadian rhythm in c-fos-like immunoreactivity in the rat brain. Neurosci Lett 120, 105-108.

Koster, R., Anderson, M., de Beer, E.J., 1959. Acetic acid for analgesic screening. Fedn Proc 18, 412.

Kovacs, K.J., 1998. C-Fos as a transcription factor: a stressful (re)view from a functional map. Neurochem Int 33, 287-297.

Lacheze, C., Coelho, A.M., Fioramonti, J., Bueno, L., 1998. Influence of trimebutine on inflammation- and stress-induced hyperalgesia to rectal distension in rats. J Pharm Pharmacol 50, 921-928.

Lanteri-Minet, M., Isnardon, P., De Pommery, J., Menetrey, D., 1993. Spinal and Hindbrain structure involved in visceroception and visceronociception as revealed by the expression of Fos, Jun and Krox-24 proteins. Neuroscience 55, 737-753.

Lüttecke, K., 1980. A three part controlled study of trimebutine in the treatment of irritable colon syndrome. Cur Med Res Op 6, 437-443. 
Martinez, V., Wang, L., Mayer, E., Tache, Y., 1998. Proximal colon distension increases Fos expression in the lumbosacral spinal cord and activates sacral parasympathetic NADPHd-positive neurons in rats. J Comp Neurol 390, 311-322.

Matsushita, M., Ikeda, M., Hosoya, Y., 1979. The location of spinal neurons with long descending axons (long descending propriospinal tract neurons) in the cat: a study with the horseradish peroxidase technique. J Comp Neurol 184, 63-80.

Mawe, G.M., Bresnahan, J.C., Beatlie, M.S., 1986. A light and electron microscopic analysis of the sacral parasympathetic nucleus after labelling primary afferent and efferent elements with HRP. J Comp Neurol 250, 33-57.

Menetrey, D., Basbaum, A.I., 1987. 1987. Spinal and trigeminal projections to the nucleus of the solitary tract: a possible substrate for somatovisceral and viscerovisceral reflex activation. J Comp Neurol 255, 439-450.

Menetrey, D., Gannon, A., Levine, J.D., Basbaum, A.I., 1989. Expression of c-fos protein in interneurons and projection neurons of the rat spinal cord in response to noxious somatic, articular, and visceral stimulation. J Comp Neurol 285, 177-195.

Menetrey, D., De Pommery, J., 1991. Origins of spinal ascending pathways that reach central areas involved in visceroception and visceronociception in the rat. Eur J Neurosci 3, 249-259.

Molander, C., Xu, Q., Grant, G., 1984. The cytoarchitectonic organization of the spinal cord in the rat: I. The lower thoracic and lumbosacral cord. J Comp Neurol 230, 133-141.

Molander, C., Grant, G., 1987. Spinal cord projections from hindlimb muscle nerves in the rat studied by transganglionic transport of horseradish peroxidase, wheat germ agglutinin conjugated horseradish peroxidase, or horseradish peroxidase with dimethylsulfoxide. J Comp Neurol 260, 246-255. 
Molander, C., Xu, Q., Rivero-Melian, C., Grant, G., 1989. Cytoarchitectonic organization of the spinal cord in the rat: II. The cervical and upper thoracic cord. J Comp Neurol 289, 375-385.

Morgan, C., Nadelhaft, I., de Groat, W.C., 1981. The distribution of visceral primary afferents from the pelvic nerve to the Lissauer's tract and the spinal gray matter and its relationship to the sacral parasympathetic nucleus. J Comp Neurol 201, 415-440.

Morgan, C.W., de Groat, W.C., Felkins, L.A., Zhang, S.J., 1991. Axon collaterals indicate broad intraspinal role for sacral preganglionic neurons. Proc Natl Acad Sci USA 88, 6888-6892.

Morgan, J.I., Curran, T., 1990. Inducible proto-oncogenes of the nervous system: their contribution to transcription factors and neuroplasticity. Prog Brain Res 86, 287-294.

Morris, G.P., Beck, P.L., Herridge, M.S., Depew, W.T., Szewczuk, MR.., Wallace, J.L., 1989. Hapten-induced model of chronic inflammation and ulceration in the rat colon. Gastroenterology 96, 795-803.

Moshal, M.G., Herron, M., 1979. A clinical trial of trimebutine in spastic colon. J Int Med Res 7, 231-234.

Nadelhaft, I., Booth A.M., 1984. The location and morphology of preganglionic neurons and the distribution of visceral afferents from the rat pelvic nerve: a horseradish peroxidase study. J Comp Neurol 226, 238-45.

Ness, T.J., Gebhart, G.F., 1990. Visceral pain: a review of experimental studies. Pain. 41, 167-234. Neuhuber, W., 1982. The central projections of visceral primary afferent neurons of the inferior mesenteric plexus and hypogastric nerve and the location of the related sensory and preganglionic sympathetic cell bodies in the rat. Anat Embryol 164, 413-425.

Neuhuber, W., 1986. The central projections of primary afferent neurons of greater splanchnic and intercostals nerves in the rat. Visceral primary afferent neurons of the inferior mesenteric plexus 
and hypogastric nerve and the location of the related sensory and preganglionic sympathetic cell bodies in the rat. Anat Embryol 174, 123-144.

Pairet, M., Ruckebusch, Y., 1989. On the relevance of non-steroidal anti-inflammatory drugs in the prevention of paralytic ileus in rodents. J Pharm Pharmacol 41, 757-761.

Pascual, J.L., Insausti, R., Gonzalo, L.M., 1989. The pelvic innervation in the rat: different spinal origin and projections in Sprague-Dawley and Wistar rats. Brain Res 480, 397-402.

Poynard, T., Regimbeau, C., Benhamou, Y., 2001. Meta-analysis of smooth muscle relaxants in the treatment of irritable bowel syndrome. Aliment Pharmacol Ther 15, 355-361.

Ren, K, and Ruda, MA., 1996. Descending modulation of Fos expression after persistent peripheral inflammation. NeuroReport 7, 2186-2190.

Ritchie, J., 1973. Pain from distension of the pelvic colon by inflating a balloon in the irritable bowel syndrome. Gut 14, 125-132.

Rivière, P.J.M., Pascaud, X., Chevalier, E., Le Gallou, B., Junien, J.L., 1993. Fedotozine reverses ileus induced by surgery and peritonitis: action at peripheral kappa-opioid receptors. Gastroenterology 104, 724-731.

Rivière, P.J.M., Pascaud, X., Chevallier, E., Junien, J.L., 1994. Fedotozine reversal of peritonealirritation-induced ileus in rats: possible peripheral action on sensory afferents. J Pharmacol Exp Ther 270, 846-850.

Roman, F.J., Lanet, S., Hamon, J., Brunelle, G., Maurin, A., Champeroux, P., Richard, S., Alessandri, N., Gola, M., 1999. Pharmacological properties of trimebutine and Nmonodesmethyltrimebutine. J Pharmacol Exp Ther 289, 1391-1397.

Scatton, B., 1993. The NMDA receptor complex. Fundam Clin Pharmacol 7, 389-400.

Sugiura, Y., Terui, N., Sosoya Y., 1989. Difference in distribution of central terminals between visceral and somatic unmyelinated primary afferent fibers. J Neurophysiol 62, 834-840. 
Toussaint, J., Cremer, M., Pintens, H., 1981. Etude en simple aveugle de la trimébutine et de la mébévérine dans le côlon irritable et la dyspepsie. Acta Ther 7, 261-268.

Traub, R.J., Pechman, P., Iadarola, M.J., Gebhart, G.F., 1992. Fos-like proteins in the lumbosacral spinal cord following noxious and non noxious colorectal distension in the rat. Pain 49, 393-403.

Traub, R.J., Herdegen, T., Gebhart, G.F., 1993. Differential expression of c-fos and c-jun in two regions of the rat spinal cord following noxious colorectal distension. Neurosci Lett 1993; 160, 121-125.

Urban, L., Thompson, S.W.N., Dray, A., 1994. Modulation of spinal excitability: co-operation between neurokinin and excitatory amino acid neurotransmitters. Trends Neurosci 17, 432-438.

Waxman, S.G., Dib-Hajj, S., Cummins, T.R., Black, J.A., 1999. Sodium channels and pain. Proc Natl Acad Sci USA 96, 7635-7639.

Wermelskirchen, D., Wilffert, B., Peters, T.J., 1992. Veratridine-induced intoxication: an in vitro model for the characterization of anti-ischemic compounds. Basic Clin Physiol Pharmacol 3, 293321.

Yasui, Y., Breder, C.D., Saper, C.B., Cechetto, D.F., 1991. Autonomic responses and efferent pathways from the insular cortex in the rat. J Comp Neurol 303, 355-374.

Zhang, X., Wenk, H.N., Gokin, A.P., Honda, C.N., Giesler, G.J. Jr., 1999. Physiological studies of spinohypothalamic tract neurons in the lumbar enlargement of monkeys. J Neurophysiol 82, 1054-1058. 


\section{FIGURE LEGENDS}

\section{Figure 1}

A: Abdominal contractions counted during visual observation of the animals for 60 min following $250 \mu \mathrm{l}$ saline subcutaneously (sc) $30 \mathrm{~min}$ before $10 \mathrm{ml} / \mathrm{kg}$ saline intraperitonealy (ip; controls) or $10 \mathrm{ml} / \mathrm{kg} \mathrm{0.6 \%}$ acetic acid (AA) ip (vehicle+AA), and in animals pre-treated sc $30 \mathrm{~min}$ before ip AA with 10 or $30 \mathrm{mg} / \mathrm{kg}$ nor-TMB dissolved in $250 \mu \mathrm{l}$ saline (nor-TMB+AA). NS: non

significant. B : Abdominal contractions counted by periods of 10 min during visual observation of the animals for $60 \mathrm{~min}$ following $10 \mathrm{ml} / \mathrm{kg} 0.6 \%$ AA ip in animals pre-treated sc $30 \mathrm{~min}$ before with $250 \mu \mathrm{l}$ saline (vehicle+AA), and in animals pre-treated sc 30 min before ip AA with 10 or 30 $\mathrm{mg} / \mathrm{kg}$ nor-TMB dissolved in $250 \mu \mathrm{l}$ saline (nor-TMB+AA). $* \mathrm{P}<0.05$ vs. vehicle $+\mathrm{AA}-$ treated animals.

\section{Figure 2}

Distribution of Fos-immunoreactive cells in 1) the lower thoracic level (T12) of the spinal cord following $0.6 \%$ ip acetic acid (AA) in animals pre-treated subcutaneously (sc) 30 min before with sc $250 \mu \mathrm{l}$ saline (vehicle+AA) (A), or sc $30 \mathrm{mg} / \mathrm{kg}$ nor-TMB dissolved in $250 \mu \mathrm{l}$ saline (nor$\mathrm{TMB}+\mathrm{AA})(\mathbf{B}) ; 2$ ) the lower lumbar level (L6) of the spinal cord following $250 \mu 1$ of $50 \%$ ethanol containing $30 \mathrm{mg}$ of trinitrobenzenesulfonic acid intracolonicaly (ic) in animals pre-treated ic 30 min before with $250 \mu \mathrm{l}$ saline (vehicle + colitis) $(\mathbf{C})$, or $30 \mathrm{mg} / \mathrm{kg}$ nor-TMB dissolved in $250 \mu 1$ saline (nor-TMB+colitis) (D). I-IIo: lamina I-IIo; V: lamina V; VII: lamina VII; X: lamina X; SPN: sacral parasympathetic nucleus. cc: central canal. Scale bar: $50 \mu \mathrm{m}$ for Fig 2 A,B,C; $80 \mu \mathrm{m}$ for Fig 2 D. 


\section{Figure 3}

A: Fos positive cells (mean nb/hemisection) in total laminae (I-IIo, V, VII and X) of the thoraco-

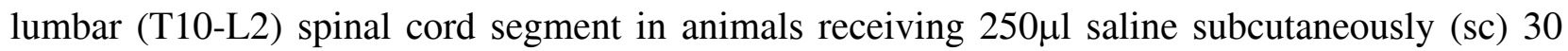
min before $10 \mathrm{ml} / \mathrm{kg}$ saline intraperitonealy (ip; controls) or $10 \mathrm{ml} / \mathrm{kg} 0.6 \%$ acetic acid (AA) (vehicle+AA), and in animals pre-treated sc 30 min before ip AA with 10 or $30 \mathrm{mg} / \mathrm{kg}$ nor-TMB dissolved in $250 \mu \mathrm{l}$ saline (nor-TMB+AA). $* \mathrm{P}<0.05$ vs. vehicle+AA-treated animals. B: Laminar distribution (mean nb/hemisection) of Fos positive cells in the thoraco-lumbar (T10 -L2) spinal cord in animals receiving $250 \mu \mathrm{l}$ saline sc $30 \mathrm{~min}$ before $10 \mathrm{ml} / \mathrm{kg}$ saline ip (controls) or $10 \mathrm{ml} / \mathrm{kg}$ 0.6\% AA (vehicle+AA), and in animals pre-treated sc 30 min before ip AA with 10 or $30 \mathrm{mg} / \mathrm{kg}$ nor-TMB dissolved in $250 \mu \mathrm{l}$ saline (nor-TMB+AA). ${ }^{*} \mathrm{P}<0.05$ vs. vehicle+AA-treated animals.

\section{Figure 4}

A: Fos-positive cells (mean nb/section) in total laminae (I-IIo $+\mathrm{V}+\mathrm{VII}+\mathrm{X})$ and in the sacral parasympathetic nucleus (SPN) of the lumbosacral (L6-S2) spinal cord in animals receiving 250 $\mu 1$ saline subcutaneously (sc) $30 \mathrm{~min}$ before $250 \mu \mathrm{l}$ saline intracolonicaly (ic; controls) or $250 \mu \mathrm{l}$ ic of $50 \%$ ethanol containing $30 \mathrm{mg}$ of trinitrobenzenesulfonic acid (TNBS) (vehicle+colitis), and in animals pre-treated ic $30 \mathrm{~min}$ before colitis with $30 \mathrm{mg} / \mathrm{kg}$ nor-TMB dissolved in $250 \mu \mathrm{l}$ saline (norTMB + colitis). $* \mathrm{P}<0.05$ vs. vehicle + colitis-treated animals. B: Laminar distribution (mean nb/section) of Fos positive cells in laminae I-IIo, V, VII, X and in the SPN of the lumbosacral (L6S2) spinal cord in animals receiving $250 \mu \mathrm{l}$ saline sc $30 \mathrm{~min}$ before $250 \mu \mathrm{l}$ saline ic (controls) or $250 \mu \mathrm{l}$ ic of $50 \%$ ethanol containing $30 \mathrm{mg}$ of TNBS (vehicle+colitis), and in animals pre-treated ic $30 \mathrm{~min}$ before colitis with $30 \mathrm{mg} / \mathrm{kg}$ nor-TMB dissolved in $250 \mu \mathrm{l}$ saline (nor-TMB + colitis). ${ }^{*} \mathrm{P}<0.05$ vs. vehicle + colitis-treated animals. 